Abstracta Iranica Abstracta Iranica

Revue bibliographique pour le domaine irano-aryen

Volume 28 | 2007

Comptes rendus des publications de 2005

\title{
Religion and Society in Qajar Iran. Londres et New York, Routledge Curzon, 2005, 482 p., fig., biblio, index.
}

Jean Calmard

\section{(2) OpenEdition}

1 Journals

Édition électronique

URL : http://journals.openedition.org/abstractairanica/17791

DOI : 10.4000/abstractairanica. 17791

ISSN : 1961-960X

Éditeur :

CNRS (UMR 7528 Mondes iraniens et indiens), Éditions de l'IFRI

\section{Édition imprimée}

Date de publication : 15 mai 2007

ISSN : 0240-8910

Référence électronique

Jean Calmard, «Religion and Society in Qajar Iran. Londres et New York, Routledge Curzon, 2005,

482 p., fig., biblio, index. », Abstracta Iranica [En ligne], Volume 28 | 2007, document 178, mis en ligne le 18 septembre 2007, consulté le 25 septembre 2020. URL : http://journals.openedition.org/ abstractairanica/17791; DOI : https://doi.org/10.4000/abstractairanica.17791

Ce document a été généré automatiquement le 25 septembre 2020.

Tous droits réservés 


\section{Religion and Society in Qajar Iran. Londres et New York, Routledge Curzon, 2005, 482 p., fig., biblio, index.}

Jean Calmard

1 Cet ouvrage collectif est le résultat d'un projet élaboré par John Gurney, John Cooper et Robert Gleave en 1995. Le propos, tout d'abord centré sur Téhéran, a été développé en 1998, avec la participation d'un plus grand nombre de chercheurs et un élargissement des sujets traités. Une conférence intitulée «The Qajar Epoch: Art, Culture and Architecture » fut organisée à Londres en septembre 1999. Les Actes, édités par Paul Luft et Chahryar Adle, sont sous presse (Routledge Curzon). Une conférence internationale, organisée à Bristol, en septembre 2000, réunit des chercheurs spécialisés sur l'Iran Qâjâr et les problèmes religieux, politiques et sociaux concernant cette période. À l'exception de six contributions, publiées ailleurs, le présent ouvrage constitue les Actes de cette conférence. Il comporte 21 articles regroupés en 5 parties. Il est dédié à John Cooper qui décéda en 1998.

Le premier article, de Robert Gleave, "Religion and society in Qajar Iran: an introduction », pp. 1-17, est une présentation détaillée du contenu de l'ouvrage par son éditeur. Il met l'accent sur l'émergence d'une réhabilitation des recherches savantes sur l'Iran Qâjâr. Les cinq parties suivantes se répartissent comme suit :

Part I. Religion and the state in the Qajar period: Said Amir Arjomand, «Political ethic and public law in the early Qajar period», pp. 21-40 (voir c.r. $n^{\circ} 169$ ) ; Robert Gleave, "Jihād and the religious legitimacy of the early Qajar state», pp. 41-70 (cf. c.r. $n^{\circ}$ 177) ; Mansur Sefatgol, «From Dār al-Salțana-yi Ișfahān to Dār al-khiläfa-yi Țihrān: continuity and change in the Safavid model of state-religious administration during the Qajars (1795-1895/1209-1313) », pp. 71-83 (voir c.r. $n^{\circ}$ 202) ; Irene Schneider, « Religious and state juridiction during Nāṣir al-Dīn Shāh's reign ", pp. 84-110 (cf. c.r. n 201). 
Part II. Religious thought in the Qajar period: Sajjad Rizvi, «Being (wujūd) and sanctity (wilāya): two poles of intellectual and mystical enquiry in Qajar Iran », pp. 113-126 (voir c.r. $n^{\circ} 305$ ) ; Todd Lawson, « Orthodoxy and heterodoxy in Twelver Shi'ism: Aḥmad al-Aḥsā’ī on Fayḍ Kāshānī (the Risālat al-'Tlmiyya) », pp. 127-154 (voir c.r. $\left.\mathrm{n}^{\circ} 185\right)$; Andrew J. Newman, "Anti-Akhbārī sentiments among the Qajar 'Ulamā': the case of Muhammad Bāqir al-Khwānsārī (d. 1313/1895)», pp. 155-173 (cf. c.r. n 190) ; Sohrab Yazdani, "Heterodox intellectuals of the Iranian Constitutional Revolution ", pp. 174-191 (cf. c.r. $\left.n^{\circ} 220\right)$.

5 Part III. Sources for the study of popular religion in Qajar Iran : Roxane HaagHiguchi, "Religion in public and private life: the case of Yaghmā-yi Jandaqi (1781-1859)», pp. 195-210 (cf. c.r. no 179) ; Christoph Werner, «Pious merchants: religious sentiments in wills and testaments », pp. 211-226 (cf. c.r. $n^{\circ} 207$ ); Nobuaki Kondo, "The Vaqf and the religious patronage of Manūchihr Khān Mu'tamad alDawlah », pp. 227-244 (cf. c.r. n 184).

Part IV. Religious minorities and Western missionaries in Qajar Iran: Abbas Amanat, « Mujtahids and missionaries: Shīì responses to Christian polemics in the early Qajar period », pp. 247-269 (cf. c.r. n 168) ; Florence Hellot, « The Western missionaries in Azerbaijani society (1835-1914)», pp. 270-292 (cf. c.r. n 181) ; Haideh Sahim, « Jews of Iran in the Qajar period: persecution and perseverance ", pp. 293-310 (cf. c.r. n 199); Juan R.I. Cole, «The evolution of charismatic authority in the Bahā'i faith (1863-1921) », pp. 311-345 (cf. c.r. $n^{\circ} 171$ ) ; Moojan Momen, «The role of women in the Iranian Bahā'i community during the Qajar period », pp. 346-369 (cf. c.r. n 189).

Part V. Religion and culture in Qajar Iran : Kamran Aghaie, « Religious rituals, social identities and political relationships in Tehran under Qajar rule, 1850s-1920s", pp. 373-392 (cf. c.r. $\mathrm{n}^{\circ}$ 167) ; Pardis Minuchehr, «The Exile Persian Press and the proconstitutionalist 'Ulam $\bar{a}$ ' of the 'Atabāt», pp. 393-400 (cf. c.r. no 216); Hormoz Ebrahimnejad, «Religion and medicine in Qajar Iran », pp. 401-428 (cf. c.r. $n^{\circ} 174$ ); Jennifer Scarce, "Some interpretations of religious and popular culture in Qajar tilework», pp. 429-448 (cf. c.r. n²00).

\section{INDEX}

Thèmes : 4.2.1. Safavides et Qâjârs

\section{AUTEURS}

JEAN CALMARD

CNRS - Paris 